\title{
Giant Polyostotic Fibrous Dysplasia: F-18-flourodeoxyglucose Positron Emission Tomography/Computerized Tomography and Radiologic Findings
}

\author{
Dev Poliostotik Fibröz Displazi: F-18-florodeoksiglukoz Pozitron Emisyon Tomografi/ \\ Bilgisayarlı Tomografi ve Radyolojik Bulgular
}

D Melis Baykara Ulusan1, (D) Tevfik Fikret Çermik²

1 University of Health Sciences Turkey, İstanbul Training and Research Hospital, Department of Radiology, İstanbul, Turkey

2University of Health Sciences Turkey, İstanbul Training and Research Hospital, Department of Nuclear Medicine, İstanbul, Turkey

\begin{abstract}
A 40-year-old man with polyostotic fibrous dysplasia underwent F-18-flourodeoxyglucose (FDG) positron emission tomography/computed tomography imaging to rule out a possible malignancy. It showed lytic, expansile and moderate to high hypermetabolic bone lesions with "ground glass" pattern and surrounded by a distinct rim of reactive bone in the right temporal bone, $8^{\text {th }}$ and $9^{\text {th }}$ ribs on the left hemithorax, T8 vertebra and sacrum. As some lesions had high F-18-FDG uptake, it was recommended to repeat the histopathological examination with suspicion of sarcomatous pathology. A second biopsy of the mass on the $8^{\text {th }}$ rib was confirmed the diagnosis of fibrous dysplasia.
\end{abstract}

Keywords: Polyostotic fibrous dysplasia, F-18 FDG PET/CT, CT, MRI

\section{$\ddot{0} Z$}

Poliostotik fibröz displazili 40 yașında erkek hastaya, olası bir maligniteyi ekarte etmek için F-18-florodeoksiglukoz (FDG) pozitron emisyon tomografisi-bilgisayarlı tomografi görüntülemesi yapılmıştır. Yapılan incelemede sağ temporal kemikte, sol 8. ve 9. kostalarda, T8 vertebra ve sakrumda litik, ekspansil, "buzlu cam" paterninde reaktif sklerotik rim ile çevrili orta-yüksek metabolizma gösteren lezyonlar saptanmıştır. Bazı lezyonlarda F-18-FDG tutulumu yüksek olduğundan, sarkomatöz patoloji şüphesiyle histopatolojik incelemenin tekrarlanması önerilmiștir. Sekizinci kostadaki kitleden yapılan ikinci biyopside fibröz displazi tanısı doğrulanmıştır.

Anahtar Kelimeler: Poliostotik fibröz displazi, F-18 FDG PET/ BT, BT, MR

\section{Introduction}

Fibrous dysplasia (FD) is a benign congenital non-neoplastic condition of children and young adults characterized by the replacement of normal cancellous bone by abnormal fibrous tissue. FD can affect one bone (monostotic, $80 \%$ ) or multiple bones (polyostotic, 20\%). When polyostotic, it tends to be unilateral. It can literally affect all bones but is mainly seen in long bones, craniofacial bones, and ribs. The polyostotic form can be seen in McCune-Albright and Mazabraud syndrome with endocrinopathies $(1,2)$.

Lesions of FD continue to grow until bone maturation occurs; they regress in adulthood or remain silent. FD is usually an incidental finding in adults and asymptomatic but it may become symptomatic with pathological fractures, secondary aneurysmatic bone cysts and very rarely with malignant transformation $(0.5 \%)(3,4)$.
The diagnoses of FD and its complications are based on physical, radiological, and histopathological examination. The use of the whole body F-18-flourodeoxyglucose (FDG) positron emission tomography/ computed tomography (PET/CT) imaging is not rare because FD shows various FDG uptake and can mimic multiple bone metastases, especially in polyostotic form $(5,6)$.

This article presents a case of polyostotic FD in a patient with the imaging and histopathological features, diagnosed during the investigation of a giant rib mass.

\section{Case Report}

A 40-year-old man presented with chest pain and a big, firm swelling on his left flank area. Magnetic resonance imaging (MRI) examination images showed a heterogenous, expansile bone mass involving the left eighth and ninth ribs and T8 vertebra. The lesion was expanding from

Cite this article as/Atıf: Baykara Ulusan M, Cermik TF. Giant Polyostotic Fibrous Dysplasia: F-18 FDG PET/CT and Radiologic Findings. İstanbul Med J 2020; 21(2): 145-7.

(c) Copyright 2020 by the University of Health Sciences Turkey, Istanbul Training and Research Hospital/istanbul Medical Journal published by Galenos Publishing House.

(C) Telif Hakkı 2020 Sağıı Bilimleri Üniversitesi Istanbul Ĕgitim ve Araştırma Hastanesi/Istanbul Tıp Dergisi, Galenos Yayınevi tarafından basılmıștır. 
the bottom of left scapula level posteriorly to the midclavicular line anteroinferiorly. The bone mass showed heterogenous intermediate signal on T2W images with cystic areas and mainly heterogenous avid enhancement with concomitant mild enhancement areas on postcontrast T1W images (Figure 1). The lesion was limited to the bone without a soft tissue component and mostly well-demarcated. However, giant cell bone tumor could not be excluded due to vertebral destruction and signal similarities. Aneurysmal bone cyst findings and some bone-forming regions were reported in the first histopathological examination. No primary tumor was found but FD and giant cell tumor of bone were highlighted as differential diagnosis.

The patient was referred for F-18-FDG PET/CT imaging to rule out a possible malignancy. It showed lytic, expansile and moderate to intense hypermetabolic bone lesions with "ground glass" pattern and surrounded by a distinct rim of reactive bone in the right temporal bone, left hemithorax, left T8 vertebra and sacrum (Figure 1-2). The F-18-FDG uptake in the right temporal bone was variable, with the maximum standardized uptake value (SUV ${ }_{\max }$ ) of 11.9. The right hemithorax lesions appeared to arise from the left eighth and ninth ribs (SUV $\left.{ }_{\max }: 15.1\right)$, with the involvement of the T8 vertebra (SUV max $: 9.6)$. FDG-avid lesions were also noted in bilateral sacral wings with a maximum SUV max $_{\text {of }} 9.8$ in the right sacral wing. As the heterogeneous and intense F-18-FDG uptake in the lesions raised concern of sarcomatous degeneration, secondary histopathological examination was recommended.

On microscopic examination, the tissue revealed irregular, bony trabeculae in a collagenous stroma with no evidence of osteoblastic rimming and lamellar bone were evident. The mesenchymal stroma surrounding the dysplastic trabeculae was relatively hypocellular. Both

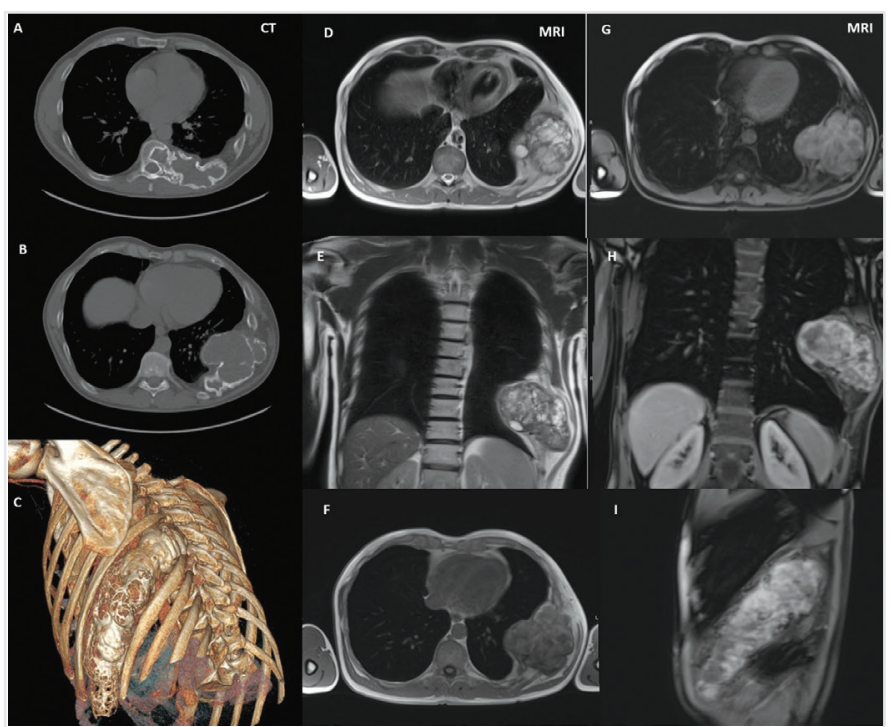

Figure 1. On the computerized tomography images, lesion affects the posterior ends of the eighth and ninth ribs, and extends to the eighth vertebral body through the costovertebral joint (A, B). Volume rendered images demonstrating heterogenous expansion of whole rib (C). In magnetic resonance imaging $\mathrm{T} 2 \mathrm{~W}$ axial and coronal images, expanse rib mass is heterogeneously hyperintense. It abuts lung. On unenhanced magnetic resonance imaging T1-weighted images the lesion is isointense with bone (D, E, F). On axial, coronal and sagittal enhanced series showing avid heterogenous enhancement on the magnetic resonance imaging images $(\mathrm{G}, \mathrm{H}, \mathrm{I})$ features were characteristics of FD. A diagnosis of polyostotic FD was made with a second biopsy of the rib mass. Informed consent was obtained from the patient to use his data in this study.

\section{Discussion}

FD accounts for approximately 7\% of benign bone tumors and is caused by an activating mutation of GNAS gene, encoding $\alpha$-subunit of stimulatory $\mathrm{G}$ protein seen in both mono and polyostotic forms, resulting in abnormal osteoblastic differentiation and increased bone turnover $(2,6)$.

The gross histological picture of FD constitutes a firm solid tan-gray mass which gradually replaces the medullary cavity and the surrounding cortical bone. It consists of uniformly cellular fibrous tissue, cytologically bland spindle cells with sparse mitotic activity. Irregular curvilinear woven bones are also present without any significant osteoblastic rimming (7).

A sudden increase in the size of a previous FD maybe due to a superimposed aneurismatic bone cyst or malignant transformation. Malignant transformation is rarely seen with an incidence of $0.5 \%$ in patients with FD. The incidence increases in patients with McCuneAlbright syndrome by nearly $4 \%$. It may develop after radiation therapy. Although the most common malign transformation is osteosarcoma, fibrosarcoma and chondrosarcoma can also be seen. Radiographic changes suggesting malignancy are lytic regions, intralesional calcification, periosteal reaction, and a cortical disruption (4,8-13). Radiologic differential diagnoses of FD include paget disease (mostly skull), simple bone cyst, giant cell tumor (mostly pelvis), non-ossifying fibroma, neurofibromatosis, and osteoblastoma. In tibia, when originates in cortex, FD is indistinguishable from adamantinoma. This distinction can be made pathologically $(5,11,12,14)$.

X-ray imaging may show not specific but characteristic features. The density of lesions varies from lytic to sclerotic. Mostly central lesions show

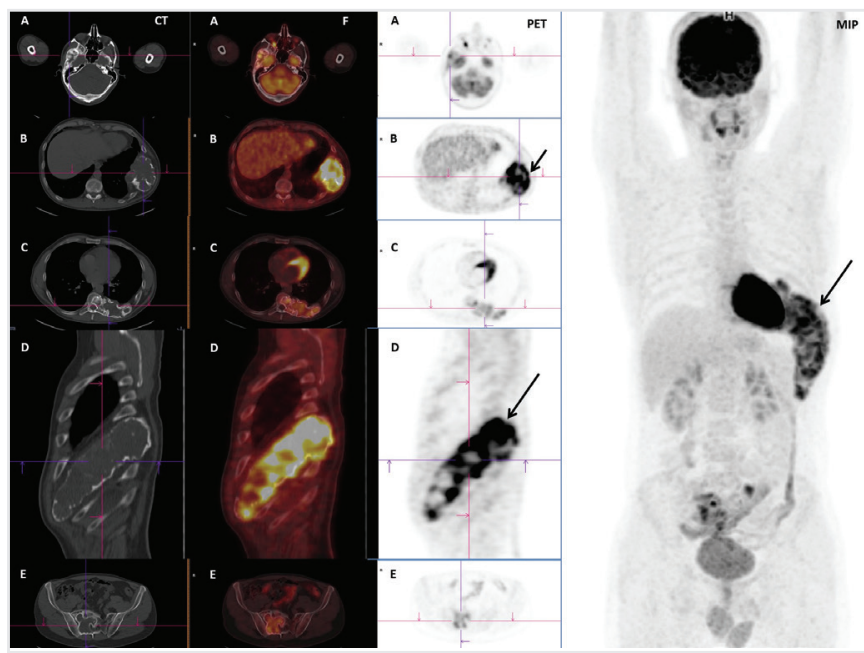

Figure 2. Positron emission tomography / computerized tomography images showed heterogeneously moderate or high pathological fluorodeoxyglucose uptake in lesions located in the right temporal bone, the $8^{\text {th }}$ and $9^{\text {th }}$ ribs at left hemithorax, $8^{\text {th }}$ thoracic vertebral body and sacrum (A, B, C, D, E and MIP). The most intense uptake was observed in lesion along the $8^{\text {th }}$ rib in the left hemithorax (arrows) (MIP: maximum intensity projection, F: fusion). 
enlargement of medulla, deformity with endosteal thinning, increased trabeculation to a characteristic "ground-glass" appearance which is formed by a mixture of immature bone and fibrous tissues $(2,4,8)$.

The conventional three-phase bone scan shows markedly increased uptake of tracer in both perfusion and the delayed phase. This high uptake is related to the bone turnover characteristic for the disorder. CT is still the best technique for delineating the extent of involvement with the typical ground glass pattern of the bone. The lesion is surrounded by a reactive sclerotic bone $(5,14)$.

F-18-FDG PET/CT imaging is also used to make a differential diagnosis. Benign bone lesions like giant cell tumor of bone can show high F-18FDG uptake, and the SUV ${ }_{\max }$ values vary according to the different stages of disease and remodeling (15).

In cases of FD, a highly variable F-18-FDG uptake was identified, between none and avid, especially in cases mimicking metastatic disease $(3,16$ 18). The highest SUV $V_{\max }$ value of 15.1 for a benign FD in our study was higher than most of the benign and some of the malignant lesions reported in the literature $(18,19)$. The report of Su et al. (19) and many other publications have discussed the necessity and usefulness of PET/ CT. The lesion diversity among the body parts and the distribution of hyper- and hypometabolic areas inside the lesions made it impossible to diagnose a lesion by PET/CT. They argued that the correct diagnosis could only be made by biopsy (17).

In patients who were followed up with FD, focal increase in SUV max $_{\text {max }}$ was evaluated in favor of early malignant transformation, while some authors reported that patients with benign proven lesions showed F-18FDG activity changes in follow-up examinations (15).

CT and MRI imaging features in our case suggested FD in the first differential diagnosis when multiple lesions were considered. The 40-year-old patient presented with a growing lesion, and high F-18FDG uptake of the lesions compared to the literature increased the suspicion of malignant transformation. When both pathology results are evaluated together, this patient with undiagnosed polyostotic FD is likely to become symptomatic due to aneurysmal bone cyst secondary to the left hemithorax lesion. In addition, repeat biopsy results from different locations were not found in favor of malignant transformation. This case shows the potential pitfalls in the interpretation of F-18-FDG PET/ CT when multiple increased uptake is seen in the skeleton, particularly in the context of suspected malignancy.

In conclusion, on F-18-FDG PET/CT imaging, the quantity of radiopharmaceutical uptake of $\mathrm{FD}$ lesions does not distinguish between a benign lesion and a lesion that has undergone malignant transformation. However, PET/CT imaging can lead to biopsy by identifying the maximum F-18-FDG-avid bone lesions and it may show multifocality of an undiagnosed polyostotic FD. And also, PET/CT may be useful for long-term follow-up of low F-18-FDG-avid FD lesions.

Informed Consent: Informed consent was obtained from the patient to use his data in this study.

Peer-review: Externally peer-reviewed.

Author Contributions: Surgical and Medical Practices - M.B.U., T.F.Ç.; Concept - M.B.U., T.F.Ç.; Design - M.B.U., T.F.C..; Data Collection and/or
Processing - M.B.U., T.F.C.; Analysis and/ or Interpretation - M.B.U., T.F.C..; Literature Search - M.B.U., T.F.Ç.; Writing Manuscript - M.B.U., T.F.Ç.

Conflict of Interest: No conflict of interest was declared by the authors.

Financial Disclosure: The authors declared that this study received no financial support.

\section{References}

1. Mandell, Jacob. Core radiology: A visual approach to diagnostic imaging. University Printing House, Cambridge: Cambridge University Press, 2013. ISBN 978-1-107-67968-9, Paperback 376-78.

2. Manaster, B. J. Diagnostic imaging. Musculoskeletal: non-traumatic disease, Second edition. Salt Lake City, UT: Elsevier, Inc., 2016. ISBN 978-0-323-392525. Pages:376-82.

3. Makis W, Probst S. Extensive polyostotic fibrous dysplasia evaluated for malignant transformation with 99mTc-MDP bone scan and 18F-FDG PET/CT. BJR Case Rep 2016; 2: 20150440.

4. Khanna V, Shori A. Case Report J0J Case Stud Polyostotic Fibrous Dysplasia: A Case Report. JOJ Case Stud 2017;3. doi:10.19080/JOJCS.2017.03.555601.

5. Aras M, Ones T, Dane F, Nosheri O, Inanir S, Erdil TY, et al. False Positive FDG PET/CT Resulting from Fibrous Dysplasia of the Bone in the Work-Up of a Patient with Bladder Cancer: Case Report and Review of the Literature. Iran I Radiol 2012; 10: 41-4.

6. Hosalkar RM, Pathak J, Swain N, Mohanty N. Pagetoid polyostotic fibrous dysplasia. BMJ Case Rep 2015; 2015. pii: bcr2014209149.

7. Kamaleshwaran KK, Joseph J, Kalarikal R, Shinto AS. Image Findings of Polyostotic Fibrous Dysplasia Mimicking Metastasis in F-18 FDG Positron Emission Tomography/Computed Tomography. Indian J Nucl Med 2017; 32: 137-9.

8. Traibi A, El Oueriachi F, El Hammoumi M, Al Bouzidi A, Kabiri el H. Monostotic fibrous dysplasia of the ribs. Interact Cardiovasc Thorac Surg 2012; 14: 41-3.

9. Hughes EK, James SLJ, Butt S, Davies AM, Saifuddin A. Benign primary tumours of the ribs. Clin Radiol 2006; 61: 314-22.

10. Diercks RL, Sauter AJ, Mallens WM. Aneurysmal bone cyst in association with fibrous dysplasia. A case report. J Bone Joint Surg Br 1986; 68: 144-6.

11. Tateishi U, Gladish GW, Kusumoto M, Hasegawa T, Yokoyama R, Tsuchiya R, et al. Chest Wall Tumors: Radiologic Findings and Pathologic Correlation. Radio Graphics 2003; 23: 1477-90.

12. DiCaprio MR, Enneking WF. Fibrous Dysplasia.Pathophysiology, Evaluation, and Treatment. J Bone Jt Surg 2005; 87: 1848.

13. Fitzpatrick KA, Taljanovic MS, Speer DP, Graham AR, Jacobson JA, Barnes GR, et al. Imaging Findings of Fibrous Dysplasia with Histopathologic and Intraoperative Correlation. Am J Roentgenol 2004; 182: 1389-98.

14. Kransdorf MJ, Moser RP, Gilkey FW. Fibrous dysplasia. Radiographics 1990; 10: $519-37$

15. Berrebi 0, Steiner C, Keller A, Rougemont A-L, Ratib 0. F-18 Fluorodeoxyglucose (FDG) PET in the Diagnosis of Malignant Transformation of Fibrous Dysplasia in the Pelvic Bones. Clin Nucl Med 2008; 33: 469-71.

16. von Falck C, Rosenthal H, Laenger F, Lotz J, Knapp WH, Galanski M. Avid uptake of [18F]-FDG in fibrous dysplasia can mimic skeletal involvement in Hodgkin's disease. Eur J Nucl Med Mol Imaging 2008; 35: 223.

17. Basu S, Baghel N, Puri A, Shet T, Merchant N. 18F-FDG avid lesion due to coexistent fibrous dysplasia in a child of embryonal rhabdomyosarcoma: Source of false positive FDG-PET. J Cancer Res Ther 2010; 6: 92.

18. Charest M, Singnurkar A, Hickeson M, Novales JA, Derbekyan V. Intensity of FDG uptake is not everything: synchronous liposarcoma and fibrous dysplasia in the same patient on FDG PET-CT imaging. Clin Nucl Med 2008; 33: 455-8.

19. Su MG, Tian R, Fan QP, Tian Y, Li FL, Li L, et al. Recognition of fibrous dysplasia of bone mimicking skeletal metastasis on 18F-FDG PET/CT imaging. Skeletal Radiol 2011; 40: 295-302. 